\title{
Media Pembelajaran Pengenalan Alat Transportasi dan Rambu Lalu Lintas Berbasis Android untuk Sekolah Dasar
}

Nadiyasari Agitha*1, Romi Saefudin², I Gede Pasek Suta Wijaya ${ }^{3}$

1,2,3 Program Studi Teknik Informatika, Universitas Mataram

\begin{abstract}
Abstrak
Alat transportasi dan rambu lalu lintas menjadi salah satu pembelajaran yang penting untuk siswa Sekolah Dasar. Tetapi banyak siswa Sekolah Dasar yang hanya mengetahui alat transportasi tanpa mengetahui rambu lalu lintas. Tujuan penelitian ini adalah untuk membangun dan membuat media pembelajaran untuk dapat memudahkan siswa mengenal alat transportasi dan rambu lalu lintas dengan menggunakan platform Android. Metode yang digunakan dalam membangun aplikasi ini adalah dengan metode waterfall yaitu di mulai dengan melakukan observasi sampai dengan pengujian sistem. Pengujian yang digunakan adalah pengujian black box testing dan Mean Opinion Score (MOS). Hasil dari pengujian black box testing adalah menu telah dapat berjalan sesuai dengan fungsinya masingmasing, sedangkan untuk MOS menghasilkan sekitar hasil sebanyak 98\% menyatakan bahwa aplikasi sudah berjalan baik. Sehingga aplikasi ini digunakan sesuai dengan kebutuhan siswa Sekolah Dasar dalam membantu mengenal alat transportasi dan rambu lalu lintas.
\end{abstract}

Kata kunci: Aplikasi Android, Pembelajaran Rambu Lalu Lintas, Alat Transportasi, Black Box Testing, MOS

\begin{abstract}
Transportation equipment and traffic signs are one of the important lessons for elementary school students. However, many elementary school students only know the means of transportation without knowing the traffic signs. The purpose of this study is to build and create learning media to make it easier for students to recognize transportation tools and traffic signs using the Android platform. The method used in building this application is the waterfall method, which starts with making observations to testing the system. The tests used are black box testing and Mean Opinion Score (MOS). The results of the black box testing test are that the menu has been able to run according to their respective functions, while for MOS, it produces about $98 \%$ results stating that the application is running well. So that this application is used in accordance with the needs of elementary school students in helping to recognize means of transportation and traffic signs.
\end{abstract}

Keywords: Mobile Application, Learning Traffic Signs, Means of Transportation, Black Box Testing, MOS

\section{PENDAHULUAN}

Lalu lintas merupakan ruang gerak yang diperlukan untuk komponen yang ada didalamnya. Lalu lintas didukung oleh pengguna jalan, rambu lalu lintas dan alat transportasi yang menjadi bagian didalamnya. Lalu lintas dan angkutan jalan dilaksanakan agar terwujudnya pelayanan yang selamat, aman, tertib dan lancar untuk pengguna jalan (Sasambe, 2016). Rambu Lalu Lintas adalah bagian dari jalan yang dapat berupa simbol, huruf, kalimat, angka dan paduan dari kesemuanya yang berfungsi sebagai tanda bagi Pengguna Jalan. Dengan adanya rambu lalu lintas, merupakan salah satu upaya untuk meminimalkan kejadian yang terjadi di jalan raya (Siddik, 2016). 
Dalam berlalu lintas, pengguna jalan merupakan salah satu komponen yang paling berpengaruh. Pengguna jalan menggunakan alat transportasi untuk dapat berlalu lintas. Pengguna jalan juga diharuskan untuk mematuhi dan mengingat simbol dari rambu lalu lintas. Pengguna jalan baiknya diedukasi sejak dini (Syakur \& Anamisa, 2018). Edukasi sejak dini telah berusaha dilakukan oleh pihak Kepolisian sebagai penanggung jawab dari lalu lintas. Pihak Kepolisian telah meluncurkan gerakan "Polisi Sahabat Anak" sebagai upaya untuk dapat meningkatkan kredibilitas Polisi dengan cara mengedukasi anak sejak dini mengenal lalu lintas (Rofifah, 2020).

Berdasarkan hasil wawancara yang dilakukan pada beberapa orang anak di tingkat Sekolah Dasar, menyimpulkan bahwa mereka banyak yang tidak mengetahui arti dari rambu lalu lintas. Mereka hanya mengetahui alat transportasi saja. Alat transportasi pun tidak semua diketahui. Android sebagai platform yang menawarkan kemudahan dalam melakukan pembelajaran telah membantu banyak siswa, terutama sebagai media pembelajaran (Aini et al., 2018; Hakky et al., 2018; Wahyuni, 2019). Media pembelajaran yang interaktif memudahkan siswa dalam mengenal gambar dan objek (Rismayana, 2018). Media pembelajaran interaktif juga tentunya dapat membantu siswa SD untuk dapat lebih mudah dan cepat dalam mengenal alat transportasi dan rambu lalu lintas.

Pada penelitian yang membahas media pembelajaran interaktif, terdapat beberapa yang juga yang menggunakan rambu lalu lintas sebagai ide penelitiannya (Syakur \& Anamisa, 2018) tetapi tidak menyertakan alat transportasi sebagai data yang saling mendukung dan berkaitan dengan rambu lalu lintas. Terdapat juga penelitian yang menyertakan pembelajaran interaktif menggunakan game sebagai media pembelajaran lalu lintas (Barokum et al., 2019), hanya saja game yang dilakukan hanya berfokus pada cara untuk berlalu lintas dengan baik tanpa adanya pembelajaran tentang alat transportasi.

Berdasarkan hal tersebut di atas, tujuan penelitian ini adalah membuat media pembelajaran berbasis android yang dapat membantu siswa SD lebih mudah mengenal objek dengan mengenal gambar dan dapat berinteraksi dengannya. Media pembelajaran ini juga disertai dengan kuis yang memudahkan siswa SD untuk dapat mengevaluasi pengetahuan tentang rambu lalu lintas dan alat transportasi yang telah dibaca dan dipelajari sebelumnya. Selain kuis, juga terdapat game yang akan dilewati berdasarkan level yang harus ditempuh oleh setiap siswa. Warna yang menarik dan gambar yang mudah diingat menjadi daya tarik untuk memudahkan siswa dalam menggunakan media pembelajaran. Pembuatan media pembelajaran rambu lalu lintas dan alat transportasi ini menjadi satu kesatuan yang tidak dapat dipisahkan, sehingga akan membantu mewujudkan Gerakan yang diinisiasi oleh Polisi serta memudahkan guru dan siswa dalam melakukan pembelajaran secara interaktif.

\section{METODE}

Metode untuk membangun sistem yang dilakukan adalah dengan menggunakan metode waterfall. Waterfall digunakan karena merupakan metode yang menerapkan Langkah yang sesuai dengan siklus hidup perangkat lunak serta mendukung pengembangan yang dapat dilakukan secara sekuensial. Langkah-langkah penelitian ini disjaikan pada gambar 1 yang merupakan diagram alir pada penelitian ini dari studi literatur sampai pengujian sistem.

Studi literatur dilakukan dengan mencari referensi teori yang relevan dengan kasus atau permasalahan yang ditemukan (Soares, 2013). Pengumpulan data dilakukan dengan dua cara observasi dan dokumentasi (Febrian \& Agitha, 2020). Observasi dilakukan dengan melakukan pengamatan langsung pada pihak Kepolisian Kota Mataram dan SD IT Anak Sholeh Mataram. Analisis data dilakukan dengan beberapa metode yaitu dengan menggunakan use case diagram, Activity Diagram, Class Diagram dan Sequence Diagram (Kurniawan, 2021). Use case diagram dari perancangan aplikasi ini dapat dilihat pada gambar 2. Gambar 2 merupakan 
diagram Use Case perancangan aplikasi dimana User berhak mengakses beberapa menu seperti halaman masuk, halaman utama, ujian, permainan, tips berkendara dan tentang.

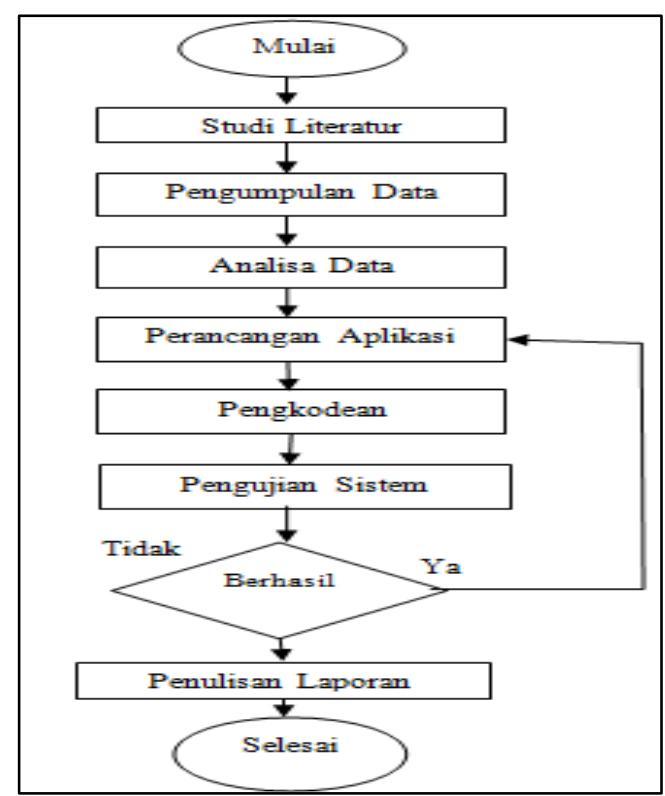

Gambar 1. Diagram Alir Penelitian

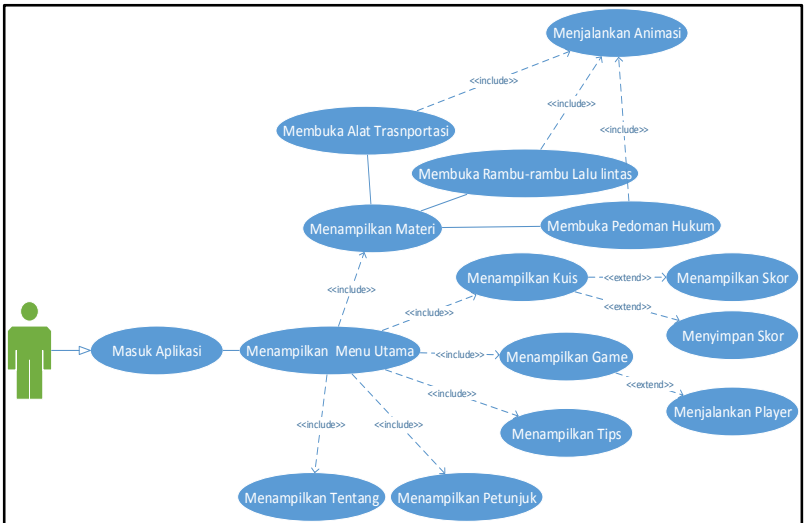

Gambar 2. Use Case Diagram Aplikasi

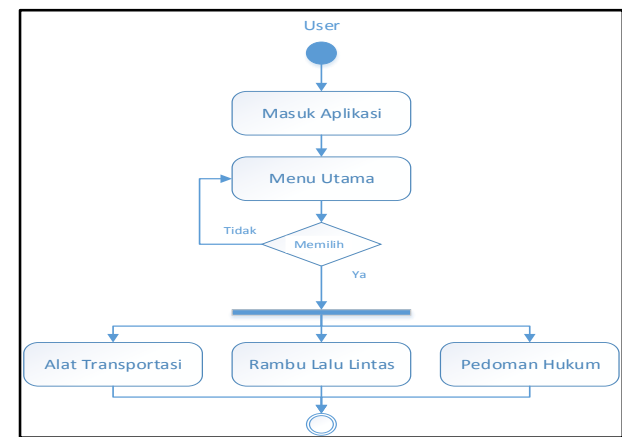

Gambar 3. Activity Diagram Menu Materi

Activity diagram (gambar 3) merupakan menu materi dari rancangan aplikasi yang akan dibangun. Activity diagram dapat berfungsi sebagai satu model gambaran statis, serta dapat juga diartikan sebagai salah satu diagram Interaction yang menjelaskan bagaimana satu operasi itu dilakukan (Anggoro et al., 2021). Dalam perancangan aplikasi ini dibutuhkan class diagram yang berfungsi sebagai diagram yang akan menggambarkan objek apa sajakah yang akan 
digunakan oleh sistem (Ikhsan et al., 2018). Diagram ini menunjukkan banyaknya objek yang terdapat dalam sistem dan serta relasi antar objek tersebut, adapun susunan dari class diagram antara nama class, atribut class, method class yang dapat dilihat pada gambar 4 .

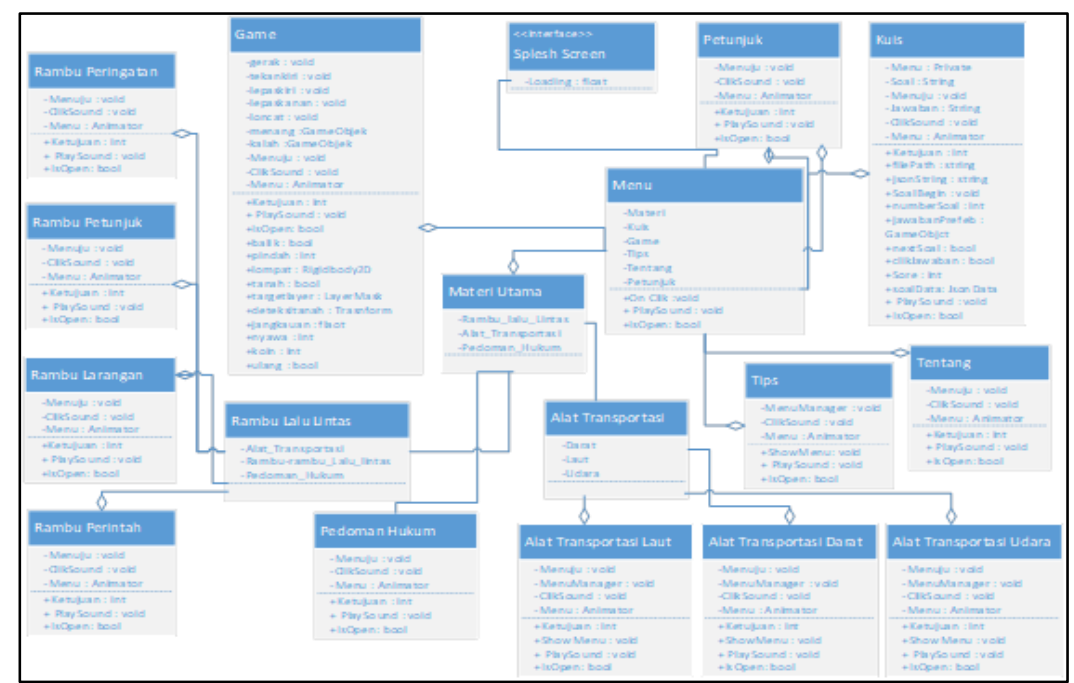

Gambar 4. Class Diagram Aplikasi Lalu Lintas

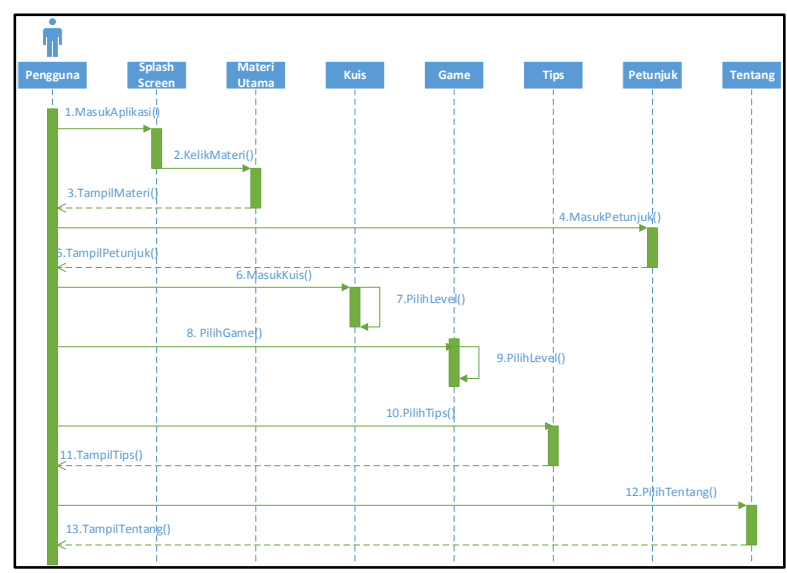

Gambar 5. Sequence Diagram Aplikasi Lalu Lintas

Gambar 5 merupakan Sequence diagram dari aplikasi media pembelajaran berbasis android, dalam diagram diatas ditunjukan untuk menentukan sejauh mana Pengguna dapat berinteraksi dengan halaman aplikasi (Putri et al., 2020). Pada Sequence diagram di atas pengguna masuk melalui halaman masuk kemudian akan muncul halaman utama, selanjutnya pengguna dapat berinteraksi dengan aplikasi melalui menu utama dimana menu utama inilah yang mengarahkan pengguna menuju menu yang lain seperti menu materi, menu ujian, menu permainan, menu tentang, menu tips berkendara serta menu bantuan.

Perancangan aplikasi merupakan early prototype untuk aplikasi yang akan dibangun (Handayani, 2019). Perancangan aplikasi berupa mock up dari aplikasi yang nantinya akan dibangun menjadi user interface yang sebenarnya . Berikut adalah penggunaan mock up untuk tampilan halaman utama. Gambar tampilan halaman utama ditampilkan pada Gambar 6. Pada gambar 6 merupakan tampilan menu utama media pembelajaran lalu lintas tersebut dimana menu utamanya terdiri dari tombol materi, tombolujian, tombol permainan, tombol tips berkendara yang baik, tombol tentang, tombol bantuan. Setiap tombol yang dipilih oleh pengguna akan muncul beberapa menu lanjutan. Selanjutnya, tahap pengkodean dilakukan dengan menggunakan bahasa pemrograman Android dan dibantu dengan menggunakan 
template dari unity. Unity digunakan untuk membuat layer editor dan memasukkan berbagai gambar yang nantinya akan menjadi data fitur yang akan berjalan pada aplikasi (Barokum et al., 2019).

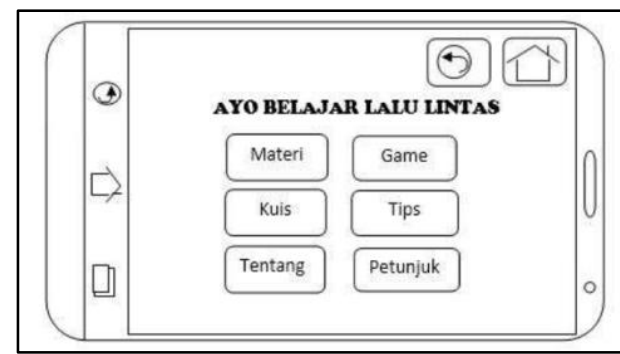

Gambar 6. Mock up Tampilan Halaman Utama

Pengujian sistem dilakukan dengan metode black box testing dan Mean Opinion Score (MOS). Pengujian dilakukan dengan black box testing dikarenakan metode ini paling pas untuk menguji kelayakan dari aplikasi yang digunakan (Andri \& Suyanto, 2020; Fadhlurrahman \& Capah, 2020; Muntohar, 2020). Sedangkan dengan metode MOS, untuk mendapatkan hasil dari pertanyaan yang telah ditanyakan kepada end-user dan mendapatkan langsung feedbacknya dengan menggunakan kuesioner (Hadisaputra et al., 2020).

\section{HASIL DAN PEMBAHASAN}

\section{Hasil}

Pada hasil merupakan tahapan membangun rancangan sistem yang telah dibahas pada pembahasan sebelumnya. Dimana hasil yang akan dilakukan dalam tahapan ini adalah membangun aplikasi dari tahap perancangan hingga penerapan audio, animasi yang menampilkan materi utama pengenalan rambu-rambu lalu lintas, kuis, game, tips, tentang dan petunjuk penggunaan aplikasi serta penerapan aplikasi dengan menggunakan Android. Dalam hasil, terdapat beberapa bahasan yaitu Animasi Aplikasi dan Tampilan Aplikasi. Pada bagian Animasi aplikasi dapat dilihat pada gambar 7 yang merupakan tampilan pengaturan base layer animator menu dimana pada tampilan tersebut dilakukan pengaturan untuk menghubungkan animasi empty, animasi open dan animasi close. Untuk menghubungkan beberapa animasi tersebut dilakukan dengan set tipe data bolean yang diberi name IsOpen pada aplikasi ini.

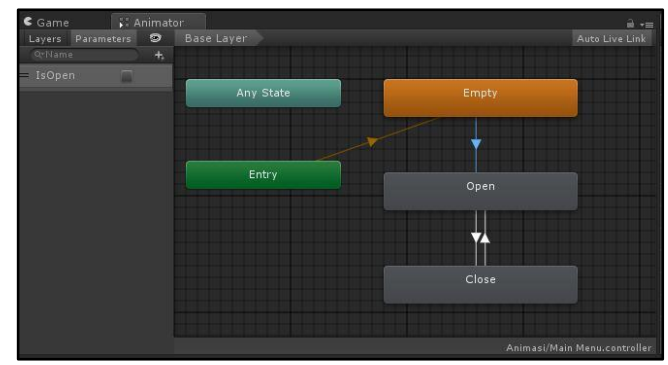

Gambar 7. Pengaturan Animator Menu

Pada tampilan Aplikasi, terdapat beberapa bagian yang digunakan untuk dapat berinteraksi dengan pengguna aplikasi. Tampilan aplikasi pada tahap ini meliputi tampilan awal, tampilan menu utama, tampilan rambu peringatan dan tampilan pengenalan lampu lalu lintas. Tampilan Splash Screen ditunjukkan pada gambar 8 yang merupakan tampilan awal dari aplikasi yang dibuat dimana halaman ini berfungsi untuk masuk ke dalam menu utama aplikasi dengan menunggu proses loading hingga 100\%. Pada Tampilan Menu Utama yang ditunjukkan oleh gambar 9 menampilkan tampilan halaman utama dari aplikasi yang dibuat. Halaman ini 
memuat menu yang akan ditampilkan yakni menu materi, menu game, menu kuis, menu tips, menu tentang dan menu petunjuk.

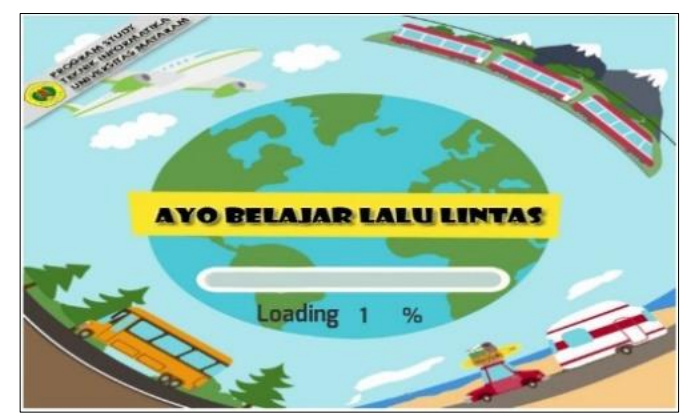

Gambar 8. Halaman Splash Screen

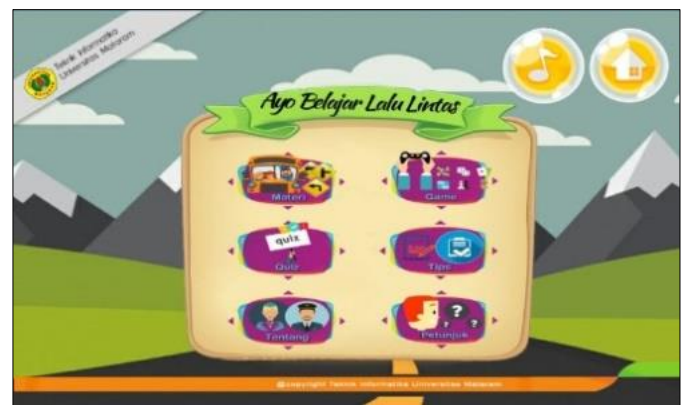

Gambar 9. Halaman Menu Utama

Pada tampilan selanjutnya adalah Tampilan Rambu Peringatan. Tampilan ini ditunjukkan oleh gambar 10 merupakan tampilan halaman untuk memperkanalkan rambu peringatan kepada user. Dimana dalam tampilan gambar tersebut terdapat gambar rambu peringatan serta keterangan teksnya, terdapat juga tombol panah untuk menampilkan materi selanjutnya.

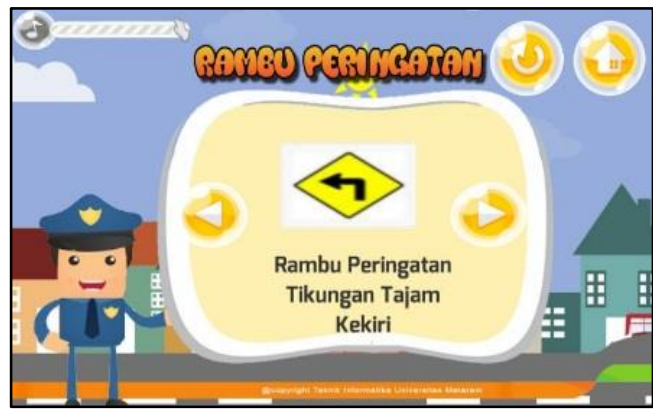

Gambar 10. Halaman Rambu Peringatan

Tampilan selanjutnya adalah tampilan mengenal lampu lalu lintas yang ditunjukkan oleh gambar 11. Pada halaman ini terdapat animasi fungsi penggunaan lampu lalu lintas, serta keterangan fungsi lalu lintas menggunakan teks, terdapat juga tombol home dan tombol untuk kembali pada pojok kanan atas tampilan, sedangkan di pojok kiri terdapat tombol untuk mengatur volume suara musik pada halaman tersebut.

Pengujian black box dilakukan untuk dapat mengusi semua fungsi dari menu yang telah dibuat. Berdasarkan pengujian yang telah dilakukan, sebagai contoh Fungsi Tombol Menu didapatkan hasil bahwa fungsi yang terdapat dalam tombol menu dapat berjalan sesuai dengan fungsinya. Untuk memudahkan dalam pengenalan rambu lalu lintas dan alat transportasi juga menggunakan menu quiz dan game. Semua tombol menu tersebut dapat berjalan dengan baik. 
Selain itu, semua tombol dan fitur yang telah dibuat, dapat berjalan sesuai dengan fungsinya masing-masing.

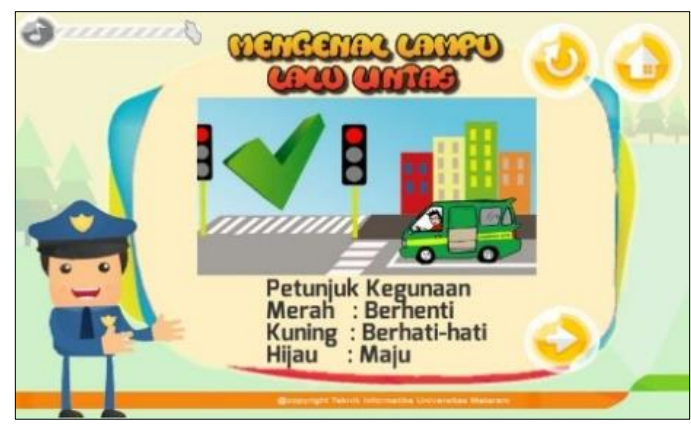

Gambar 11. Halaman Mengenal Lampu Lalu Lintas

Pengujian MOS yang dilakukan dengan responden sebanyak 30 orang. Responden yang menjawab pertanyaan kuesioner berasal dari guru dan polisi, siswa SD dan mahasiswa Teknik Informatika. Dari hasil pengujian kuisioner yang dilakukan pada Guru dan Polisi (lihat gambar 12), hasil dari perhitungan rata-rata seluruh peryataan dengan kategori baik, didapatkan nilai $98 \%$ untuk kategori tidak baik didapatkan nilai $2 \%$ dan kategori tidak tahu sebanyak $0 \%$.

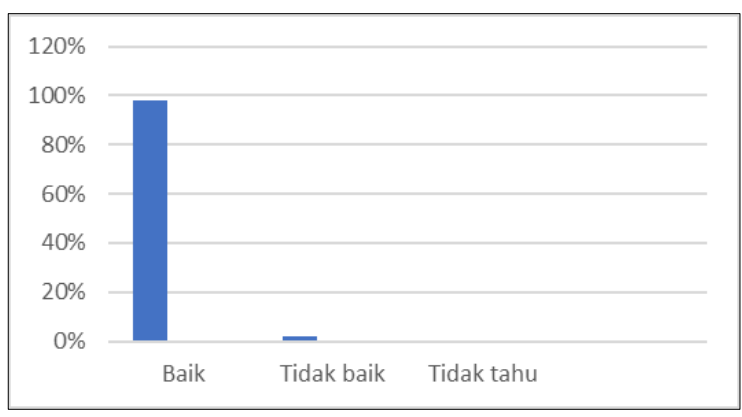

Gambar 12. Grafik akumulasi Persentase rata-rata jawaban responden (Guru dan Polisi)

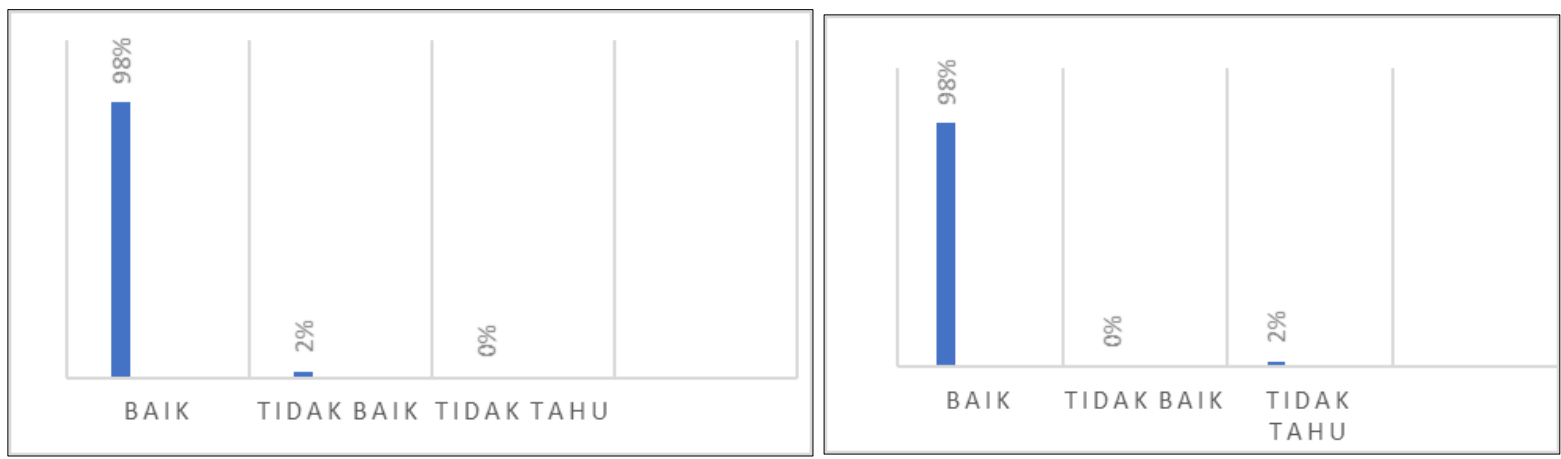

Gambar 13. Grafik rata-rata jawaban responden (kiri) (Siswa Sekolah Dasar) Grafik rata-rata jawaban responden (kanan) (Mahasiswa TI.)

Berdasarkan hasil pengujian dengan menggunakan kuesioner pada siswa SD yang ditunjukkan pada gambar 13, hasil dari perhitungan rata-rata seluruh pernyataan dengan kategori baik, didapatkan nilai $98 \%$ untuk kategori tidak baik didapatkan nilai $0 \%$ dan kategori tidak tahu sebanyak $2 \%$. Dan dari hasil pengujian dengan menggunakan kuesioner pada Mahasiswa Teknik Informatika, hasil dari perhitungan rata-rata seluruh peryataan dengan kategori baik, didapatkan nilai $98 \%$ untuk kategori tidak baik didapatkan nilai $2 \%$ dan kategori tidak tahu sebanyak $0 \%$. 


\section{Pembahasan}

Melalui hasil dari pengujian yang telah diberikan, didapatkan bahwa responden baik dari kepolisian, guru Sekolah Dasar, murid Sekolah Dasar dan mahasiswa Teknik Informatika sebagai yang mengerti dalam develop aplikasi, terdapat hasil yang baik. Hasil tersebut terlihat pada rekap kuesioner yang telah dilaksanakan. Berdasarkan pertanyaan-pertanyaan yang dikategorikan untuk setiap user telah mewakili user dalam menjawab sesuai perannya (Afuan, 2019). Pertanyaan-pertanyaan tersebut dikategorikan berdasarkan parameter pengujian yaitu Guru dan Polisi, siswa SD dan Mahasiswa Teknik Informatika. Jenis pertanyaan untuk Guru dan Polisi diantaranya adalah menanyakan apakah aplikasi mudah digunakan untuk siswa SD, apakah aplikasi ini telah memberikan informasi untuk dapat mengetahui informasi mengenai rambu dan alat transportasi, serta apakah materi yang disampaikan untuk pengenalan transportasi telah sesuai dengan materi sebenarnya. Sedangkan untuk siswa SD, jenis pertanyaannya adalah apakah aplikasi mudah digunakan, apakah aplikasi ini menarik, apakah informasi yang disajikan mudah dimengerti, dan apakah dengan menggunakan aplikasi ini dapat terbantu untuk mengenal alat transportasi dan rambu lalu lintas.

Pada mahasiswa Teknik Informatika, jenis pertanyaannya adalah tentang tampilan dan desain pengalaman pengguna. Diantaranya adalah pertanyaan tentang warna, pemilihan tulisan, kesesuaian animasi dan kesesuaian ilustrasi musik yang digunakan. Jika dibandingkan dengan penelitian (Syakur \& Anamisa, 2018) dan (Barokum et al., 2019), aplikasi android yang dibuat ini telah mendapatkan persetujuan dari pihak SD dan pihak kepolisian. Selain itu, aplikasi ini juga telah disertai dengan kuis yang akan memudahkan siswa dan guru dalam mengevaluasi pemahaman siswa SD dalam mempelajari alat transportasi dan rambu lalu lintas. Terdapat beberapa level yang dapat dilalui oleh siswa SD sehingga memudahkan dalam memahami materi alat transportasi dan rambu lalu lintas.

\section{SIMPULAN}

Aplikasi alat bantu ajar pengenalan alat transportasi dan rambu-rambu lalu lintas pada siswa sekolah dasar dapat memudahkan siswa dalam mempelajari materi pengenalan alat transportasi dan rambu-rambu lalu lintas dengan menggunakan Smartphone Android. Fitur yang disediakan dalam aplikasi pengenalan alat transportasi dan rambu lalu lintas ini berisikan animasi, gambar, teks dan suara sehingga aplikasi dapat menarik minat belajar siswa sekolah dasar tentang pengenalan alat transportasi dan rambu-rambu lalu lintas. Serta dari hasil kuesioner yang diberikan kepada responden menunjukan bahwa hasil pengujian yang dilakukan telah sesuai dengan harapan. Kuesioner yang disebarkan menunjukkan rata-rata hasil 98\% yang menilai baik untuk pengguna dari Guru, Polisi, siswa SD dan Mahasiswa Teknik Informatika. Dari kuesioner tersebut dapat disimpulkan bahwa aplikasi pengenalan alat transportasi dan rambu-rambu lalu lintas dapat berjalan dengan baik dan sesuai dengan harapan.

\section{REFERENSI}

Afuan, L. (2019). Rancang Bangun Sistem Informasi Bank Sampah di Desa Paguyangan. Edumatic: Jurnal Pendidikan Informatika, 3(2), 99-108. https://doi.org/10.29408/edumatic.v5i1.3171

Aini, N., Wirasasmita, R. H., \& Uska, M. Z. (2018). Pengembangan Mobile Learning Berbasis Android Pada Mata Pelajaran Jaringan Dasar. Edumatic: Jurnal Pendidikan Informatika, 2(1), 34-41.

Andri, A., \& Suyanto, S. (2020). Pengembangan Aplikasi Lelang Karet Berbasis Mobile Sebagai Pendukung Akses Informasi Lelang. Edumatic: Jurnal Pendidikan Informatika, 4(2), 85-94.

Anggoro, D., Sakti, D. V. S. Y., \& Waluyo, S. (2021). Implementasi Sistem Informasi Berbasis 
QR Code Guna Mencegah Kerumunan dalam Antrian Wisuda. Edumatic: Jurnal Pendidikan Informatika, 3(2), 99-108. https://doi.org/10.29408/edumatic.v5i1.3383

Barokum, M. K., Amna, A. R., \& Armin, A. P. (2019). Game Pembelajaran Rambu Lalu Lintas Berbasis Android. Konvergensi, 14(1), 11-17. https://doi.org/10.30996/konv.v14i1.2767

Fadhlurrahman, M. F. F., \& Capah, D. A. H. (2020). Aplikasi Penyewaan Lapangan Futsal Berbasis Web. Edumatic: Jurnal Pendidikan Informatika, 4(2), 30-39.

Febrian, D. G., \& Agitha, N. (2020). Analisa Kepuasan Mahasiswa Terhadap Kegiatan Belajar Mengajar Di Program Studi Teknik Informatika Universitas Mataram Menggunakan Metode Importance Performance Analysis. Journal of Computer Science and Informatics Engineering (J-Cosine), 4(2), 92-99. https://doi.org/10.29303/jcosine.v4i2.85

Hadisaputra, R., Agitha, N., \& Albar, M. A. (2020). Rancang Bangun Aplikasi Pemesanan Kue Berbasis Mobile pada Toko Kue Primadona. Jurnal Teknologi Informasi, Komputer, Dan Aplikasinya (JTIKA), 2(1), 50-56.

Hakky, M. K., Wirasasmita, R. H., \& Uska, M. Z. (2018). Pengembangan media pembelajaran berbasis android untuk siswa kelas x pada mata pelajaran sistem operasi. Edumatic: Jurnal Pendidikan Informatika, 2(1), 24-33.

Handayani, S. (2019). Penerapan Mikroskop Digital dengan Bantuan Smartphone Android sebagai Media Pembelajaran IPA. SAP (Susunan Artikel Pendidikan), 4(1), 46-52. https://doi.org/10.30998/sap.v4i1.3611

Ikhsan, M., Widiartha, I. B. K., \& Agitha, N. (2018). Rancang Bangun Sistem Informasi Geografis Kependudukan di Dinas Kependudukan dan Pencatatan Sipil Kota Mataram. Journal of Computer Science and Informatics Engineering (J-Cosine), 2(2), 112-119. https://doi.org/10.29303/jcosine.v2i2.98

Kurniawan, R. B. (2021). Rancang Bangun Sistem Informasi Konsultasi Dan Penjadwalan Fisioterapi Penyakit Bell'S Palsy (Studi Kasus Klinik Griya Fisioterapis). Jurnal Teknologi Informasi, Komputer, Dan Aplikasinya (JTIKA), 3(1), 51-61. https://doi.org/10.29303/jtika.v3i1.129

Muntohar, A. (2020). Sistem Informasi Data Klien Berbasis Java Pada Kantor Notaris dan PPAT Arif. Edumatic: Jurnal Pendidikan Informatika, 4(2), 58-67. https://doi.org/10.29408/edumatic.v4i2.2515

Putri, R. A., Albar, M. A., \& Agitha, N. (2020). Rancang Bangun Aplikasi Tes Psikologi Online Berbasis Web untuk Menunjang Keputusan Kelas Peminatan Siswa (Studi Kasus Biro Instrumentasi Bimbingan Konseling Empatik Mataram). Journal of Computer Science and Informatics Engineering (J-Cosine), 4(1), 53-62. https://doi.org/10.29303/jcosine.v4i1.312

Rismayana, A. H. (2018). Aplikasi Pengenalan Lagu Anak-Anak Berbasis Android. 12(1), 7582. https://doi.org/10.31227/osf.io/d28hw

Rofifah, D. (2020). Polisi Sahabat Anak. In Universitas Atma Jaya, Yogyakarta.

Sasambe, R. (2016). Kajian Terhadap Penyelesaian Pelanggaran Peraturan Lalu Lintas oleh Kepolisian. Lex Crimen, 5(1), 82-90.

Siddik, A. (2016). Penegakan Hukum Terhadap Pelanggaran Lalu Lintas Anak Di Bawah Umur Di Polrestabes Bandung 12. Tesis. Program Studi Ilmu Hukum: UIN Sunan Gunung Jati.

Soares, A. P. (2013). Pengertian Lalu Lintas. Journal of Chemical Information and Modeling, 53(9), 1689-1699.

Syakur, M. A., \& Anamisa, D. R. (2018). Rancang Bangun Aplikasi Pembelajaran RambuRambu Lalu Lintas Berbasis Android Untuk Siswa Sekolah Dasar. Jurnal Ilmiah Pangabdhi, 4(1), 69-74.

Wahyuni, R. (2019). Pembelajaran Tajwid Berbasis Android untuk Siswa Tingkat Dasar. Jurnal Ilmu Komputer, 8(1), 118-122. 